\title{
MODEL PENDIDIKAN ISLAM NUSANTARA
}

\author{
Inayah \\ Universitas Islam Negeri Walisongo \\ email : inayah@walisongo.ac.id
}

Abstract: The development of Islamic education in Indonesia, among others, is marked by the gradual emergence of various educational institutions, ranging from very simple ones, to stages that are considered modern and complete. The research method in this article is qualitative with library research. Literature research through library research based on literature. This study aims to photograph the model of Islamic education in the archipelago. The results of this study indicate that changes in Islamic educational institutions, both classical and modern; starting from homes, mosques, Islamic boarding schools, schools to boarding schools and Islamic universities is a metamorphosis of Islamic educational institutions in the archipelago.

Keywords: Educational Model, Islam Nusantara

Abstrak: Perkembangan pendidikan Islam di Indonesia antara lain ditandai oleh munculnya berbagai lembaga pendidikan secara bertahap, mulai dari yang amat sederhana, sampai dengan tahap-tahap ynag sudah terhitung modern dan lengkap. Metode penelitian pada artikel ini berjenis kualitatif dengan penelitian kepustakaan (librabry research). Penelitian kepustakaan melalui riset kepustakaan yang berdasarkan pustaka. Penelitian ini bertujuan untuk memotret model Pendidikan islam nusantara. Hasil dari penelitian ini menunjukkan bahwa Perubahan lemabaga-lembaga pendidikan Islam, baik klasik maupun modern; mulai dari rumah, masjid, pesantren madrasah, sekolah 
hingga boardingschool dan Universitas Islam merupakan metamorfosa kelembagaan pendidikan Islam di nusantara.

Kata kunci : Model Pendidikan, Islam Nusantara

\section{A. PENDAHULUAN}

Perkembangan pendidikan Islam di Indonesia antara lain ditandai oleh munculnya berbagai lembaga pendidikan secara bertahap, mulai dari yang amat sederhana, sampai dengan tahaptahap ynag sudah terhitung modern dan lengkap. Lembaga pendidikan Islam telah memainkan fungsi dan perannya sesuai dengan tuntutan masyarakat dan zamannya. Perkembangan lembag-lembaga pendidikan tersebut telah menarik perhatian para ahli baik dari dalam maupun luar negeri untuk melakukan studi ilmiah secara konfrehensif.

Di Indonesia sendiri, perkembangan pendidikan tumbuh cukup subur. Pendidikan ini tidak hanya diselenggarakan oleh pemerintah (negeri) tetapi juga yayasan (swasta). Beragamnya pendidikan di Indonesia saat ini merupakan hasil negosiasi panjang yang berlangsung dinamis sejak ratusan tahun silam. Salah satu potret perkembangan pendidikan di Indonesia yang menarik dikaji adalah pendidikan Islam. Pendidikan ini telah berabad-abad umurnya. Keberadaannya muncul seiring 
datangnya Islam ke Indonesia yang diperkirakan telah ada sejak abad 7 dan mulai mapan sejak abad 13. ${ }^{1}$

Salah satu potret perkembangan pendidikan di Indonesia yang menarik dikaji adalah pendidikan Islam. Pendidikan ini telah berabad-abad umurnya. Keberadaannya muncul seiring datangnya Islam ke Indonesia yang diperkirakan telah ada sejak abad 7 dan mulai mapan sejak abad 13. Selama kurun waktu tersebut, Islam dan berbagai atribut pendidikannya mampu berkembang hingga ke pelosok-pelosok desa dan diasup oleh segala lapisan masyarakat meski dalam akses dan kadar pemahaman yang berbeda-beda. Islam berkembang begitu cepat, baik secara agama, politik, sosial maupun kultural. Tidak ketinggalan, Islam juga menempatkan bidang pendidikan sebagai corong utama Islamisasi. Islam dan pendidikan menjadi satu kesatuan yang sulit dipisahkan. Di mana ada Islam, di situ pula terdapat pendidikan Islam dengan berbagai varian, model dan tingkatannya. Dalam usianya yang sudah tua, sistem pendidikan Islam di nusantara telah beberapa kali bermetamorfosis. Sehingga oleh para sejarawan muncul istilah pendidikan Islam modern dan tradisional, untuk merujuk adanya perubahan atau pergeseran sistem atau corak pendidikan.

\footnotetext{
${ }^{1}$ Daliman, Islamisasi dan Perkembangan Kerajaan-Kerajaan Islam di Indonesia. Yogyakarta: Ombak. 2012: hlm. 32-37)
} 
Keduanya memiliki perbedaan sistem dalam penyelenggaraan pendidikan, meski tetap terdapat persamaan dalam beberapa aspek tertentu yang memang masih dipertahankan.

Selain itu, di Indonesia juga terdapat Pesantren sebagai salah satu alternatif jalur penyebaran Islam di Bumi Nusantara ini. Kiprah pesantren dalam berbagai hal sangat dirasakan oleh masyarakat. Salah satu yang menjadi contoh utama adalah, selain pembentukan kader-kader ulama dan pengembangan keilmuan Islam, juga merupakan gerakan-gerakan protes terhadap pemerintah kolonial Hindia Belanda. Protes tersebut selalu dimotori dari dan oleh kaum santri. Setidaknya dapat disebutkanya misalnya; pemberontakan petani di CilegonBanten 1888, (Kartodirjo, 1993). Jihad Aceh 1873 (Kartodirjo, 1993, pp. 250-252). gerakan yang dimotori oleh H. Ahmad Ripangi Kalisalak 1786-1875 dan yang lainnya merupakan fakta yang tidak dapat dibantah bahwa pesantren mempunyai peran yang cukup besar dalam perjalanan sejarah Islam di Indonesia. ${ }^{2}$

\section{B. METODE PENELITIAN}

Metode penelitian pada artikel ini berjenis kualitatif dengan penelitian kepustakaan (librabry research). Penelitian

${ }^{2}$ A. Steenbrink Karel, Pesantren, Sekolah dan Madrasah, Pendidikan Islam dalam Kurun Modern. Jakarta, LP3ES, 1994. Hlm 187 
kepustakaan melalui riset kepustakaan yang berdasarkan pustaka yakni sumber utamanya berupa data-data kepustakaan berupa buku, manuskrip, kitab-kitab, maupun sumber-sumber lain yang berupa dokumentasi lainnya. Ada dua sumber pokok dalam penelitian ini, yakni sumber primer dan sekunder. alam hal ini menggunakan jurnal penelitian, majalah, koran, dan lain sebagainya.

\section{HASIL DAN PEMBAHASAN}

\section{Pendidikan Islam Tradisional Dan Modern Di Nusantara}

Metamorfosa kelembagaan pendidkan Islam nusantara merupakan perkembangan pesantren yang membuka madrasah, sekolah, bahkan Pendidikan Tinggi. Kajian ini sebagian besar diambil dari ekstrak artikel penulis yang dipublikasikan pada Jurnal Muqodimah. Dinamika sosial budaya di Indonesia telah membawa pesantren mengalami perubahan yang signifikan tanpa meninggalkan nilai- nilai luhur (inti ajaran Islam) yang dianutnya. ${ }^{3}$ Karel A. Steenbrink mengajukan tesis bahwa Pesantren akan berubah menjadi Madrasah dan Sekolah. ${ }^{4}$ Sampai di sini, eksistensi

${ }^{3}$ Azyumardi Azra, Pendidikan Islam, Tradisi dan Modernisasi Menuju Milineum Baru, (Bandung: Mizan), hlm. 85 LP3ES, 1986)

${ }^{4}$ Karel A. Steenbrink, Pesantren Madrasah Sekolah, (Jakarta: 
pesantren sebagai lembaga pendidikan tradisional tetap eksis di zaman modern. ${ }^{5}$ Perkembangan mutakhir menunjukan bahwa pesantren mengalami "metamorfosa" sekaligus enginspirasi lahirnya Sekolah Islam Terpadu, Full Day School dan terlebih lagi Boarding School. Ketiga bentuk lembaga pendidikan Islam yang disebutkan terakhir itu merupakan titik balik perkembangan Pesantren. Disebut titik balik karena pada dasarnya sekolah Islam terpadu adalah sekolah umum yang memperbanyak muatan pelajaran agamanya, sedangkan Pesantren adalah pendidikan agama yang dimasuki pelajaran umum.

Lembaga pendidikan Islam pertama kali adalah rumah sahabat tertentu yang paling terkenal adalah Dâr al Arqâm. Setelah masyarakat Islam terbentuk, barulah pendidikan Islam dilaksanakan di masjid. ${ }^{6}$ Oleh karenanya Tibawi mengatakan bahwa the mosques, became the first scools in Islam. ${ }^{7}$ Para peneliti sejarah pendidikan Islam menyebutkan bahwa pendidikan Islam formal mulai terbentuk bersamaan

5 Mujamil Qomar, Dari Transformasi Metodologi Menuju Demokratisasi Institusi, (Jakarta, Erlangga, 2007), hlm. 16

${ }^{6}$ Azyumardi Azra, Pendidikan Islam Tradisi dan Modernisasi Menuju Milenium Baru, (Jakarta: Logos Wacana Ilmu, 1999), hlm.vii

${ }^{7}$ A.L. Tibawi, Islamic Education Its Traditions and Modernization into the Arab Nasional Sytems, (London: Luzac \& Company LTD), hlm. 24 
dengan lahirnya madrasah. Fazlur Rahman meyebutkan lembaga-lembaga pendidikan Islam sebelum madrasah adalah kuttab, halaqah, perpustakaan dan baitul hikmah. ${ }^{8}$

Timbulnya pemikiran pembaharuan Islam baik dalam bidang teknologi, sosial, dan pendidikan diawali dan dilatar belakangi oleh pembaruan pemikiran Islam yang datang dari Mesir, dimulai sejak kedatangan Napoleon. Kesadaran umat Islam tentang pentingnya arti pembaharuan adalah ketika umat Islam menyadari ketertinggalan dalam bidang ilmu pengetahuan dan teknologi, begitu juga dalam bidang militer dari bangsa Eropa. ${ }^{9}$

Paradigma baru pendidikan Islam yang dimaksud di sini adalah pemikiran yang terus menerus harus dikembangkan melalui pendidikan untuk merebut kembali pendidikan IPTEK, akan tetapi tidak melupakan pendidikan

${ }^{8}$ Fazlur Rahman, Islam, terj. Ahsin Muhammad, Bandung: Pustaka, 1994, hlm.263-267. Syalabi menyebutkan lembaga pendidikan Islam sebelum berkembangnya madrasah adalah al Kuttâb untuk belajar membaca dan menulis, al Kuttâb untuk belajar al Qur'an dan dasar-dasar agama, Istana, pasar-pasar dan toko buku, rumah-rumah ulama, solun sastra, badiyah dan masjid. Lihat, Ahmad Syalabi, Târîkh al Tarbiyah al Islâmiyyah, (al Qâhirah: al Maktabah al Anjilu, 1960,) hlm.34-94.

${ }^{9}$ Haidar Putra Daulay, Dinamika Pendidikan Islam di Asis Tenggara (Jakarta: Rineka Cipta.2009), hlm. 28 
agama, sebagaimana zaman keemasan dulu. Pencarian paradigma baru dalam pendidikan Islam di mulai dari konsep manusia menurut Islam, pandangan Islam terhadap IPTEK, dan setelah itu baru dirumuskan konsep atau sistem pendidikan Islam secara utuh.

sudah semestinya lembaga pendidikan tidak hanya mengajarkan tentang ulum al-din, tetapi juga harus mengajarkan tentang IPTEK untuk menjwab tantangan zaman. Prinsip-prinsip lain dalam paradigma baru pendidikan Islam yang ingin dikembangkan adalah: tidak ada dikotomi antara ilmu dan agama; ilmu tidak bebas nilai tetapi bebas di nilai; mengajarkan agama dengan bahasa ilmu pengetahuan dan tidak hanya mengajarkan sisi tradisional, melainkan sisi rasional. ${ }^{10}$

Steenbrink, menyebutkan ada beberapa faktor pendorong pembaruan lembaga pendidikan Islam, yaitu:

a. Banyaknya pemikiran untuk kembali ke Al-Qur'an dan hadits

b. Sifat perlawanan nasional terhadap penguasa kolonial belanda

${ }^{10}$ Abudin Nata, 2009, Rekonstruksi Pendidikan Islam (Jakarta: Rajawali Press). Hlm. 75 
c. Adanya usaha-usaha dari umat Islam untuk memperkuat organisasinya di bidang sosial dan ekonomi

d. Ketidakpuasan masyarakat terhadap metode tradisional dalam mempelajari studi agama.

Peristiwa ini menimbulkan kesadaran umat Islam untuk mengubah diri. Kesadaran itu menimbulkan fase pembaruan dalam periodesasi sejarah Islam. Fase pembaruan itu muncul sebagai jawaban terhadap tuntutan kemajuan zaman dan sekaligus juga sebagai respon umat Islam atas ketertinggalan mereka ketika itu dalam bidang ilmu pengetahuan. Pendidikan modern merupakan bentuk perkembangan dari situasi yang menjadi tuntutan dalam kompetisi global, dimana berkembangnya pengetahuan dan tekhnologi secara drastis telah membuka kesadaran pemerintah, pendidik, dan masyarakat untuk bersama-sama membaca perubahan dan perkembangan zaman.

Mudahnya akses tekhnologi informasi telah memberikan pengaruh yang luar biasa dalam sendi-sendi kehidupan masyarakat. Tekhnologi informasi merupakan salah satu bentuk dalam kerangka menghadapi arus budaya global, sehingga pendidikan diharapkan mampu mengontrol dan memfilter arus westernisasi yang semakin merambah kedalam dunia pendidikan itu sendiri. 
Modernisasi sebagai sebuah gagasan pendidikan ingin memberikan kesetaraan dan pengakuan akan ragam budaya yang memiliki sejarah panjang. Parktek mengenai berjalannya pendidikan modern diberbagai negara, baik di barat maupun di timur telah menghasilkan kesepakatan bersama (mutual agrement) bahwa salah satu pilar pendidikan adalah "living together" yakni memberikan latihan dan keterampilan kepada para siswa akan pentingnya pengakuan dan penghargaan kepada orang yang memiliki ragam bahasa, budaya, etnis, maupun agama. ${ }^{11}$

\section{Pendidikan Pesantren di Nusantara}

Pada mulanya pesantren tumbuh di desa sebagai lembaga keagamaan, khususnya tempat orang-orang desa belajar agama dari ulama/kyai. Tetapi pada prakteknya ia tumbuh melampai batasnya. Orang-orang ke pesantren bukan hanya untuk belajar agama, tetapi juga minta penyelesaian perkara atau kekisruhan antar warga. Bahkan di beberapa pesantren orang minta pengobatan secara spiritual. Pada dimensi lain pesantren juga masuk ke garapan politik yang cukup berpengaruh. Gerakan menentang

${ }^{11}$ Samsun Niam, Pendidikan Multi Kultur, Radar Jember, kamis 28 oktober 2010, hal 39 
penjajahan, penumpasan PKI sampai ke gerakan-gerakan partai di masa Orde Baru tidak sedikit berbasis di pesantren. ${ }^{12}$

Berkaitan dengan eksistensi pesantren di tengah arus globalisasi, pesantren juga dituntut melakukan pembenahan dengan lebih akomodatif terhadap perubahan zaman yang serba cepat. Oleh karena itu pesantren perlu menyusun konsep manajemen dan kurikulum. M. Sulthon dan Moh. Khusnuridlo menyatakan bahwa manajemen yang dapat diterapkan dalam sistem pesantren yaitu Manajemen Berbasis Pondok Pesantaren (MBPP). MBPP yaitu manajemen yang dianalisis dengan pendekatan sistem yaitu dari segi input-proses-output. ${ }^{13}$

Karakteristik pesantren yang efektif diantaranya memiliki input dengan karakteristik sebagai berikut:

a. Adanya kebijakan, tujuan dan sasaran mutu yang jelas.

b. Sumber daya tersedia dan siap.

${ }^{12}$ Zamakhsyari Dhofir, Tradisi Pesantren, LP3ES, Jakarta, 1992, hlm. 49

${ }^{13}$ M. Sulthon dan Moh Khusnuridlo, Manajemen Pondok Pesantren dalam Perspektif Global, (Yogyakarta: LaskBang Pressindo, 2006), hlm. 33 
c. Staf yang kompeten, berdedikasi tinggi dan berakhlakqul karimah.

d. Memiliki harapan prestasi yang tinggi.

e. Fokus pada pelanggan (khususnya santri).

f. Adanya input manajemen yang memadai.

\section{KESIMPULAN}

Perubahan lemabaga-lembaga pendidikan Islam, baik klasik maupun modern; mulai dari rumah, masjid, pesantren madrasah, sekolah hingga boardingschool dan Universitas Islam merupakan metamorfosa kelembagaan pendidikan Islam di nusantara. Selanjutnya, metamorfosa tersebut menuntut adanya perubahan apradigma pembelajaran pendidikan Islam secara mendasar. Perubaha paradigma itu (sorogan, bandogan, hingga exsperimental sciences, integrasi ilmuwan dan ulama serta rintisn manajemen pendidikan islam yang otentik) yang kemudian disebut dengan istilah metamorfosa pembelajaran pendidikan Islam.

Pesantren merupakan pendidikan non formal yang mampu menjadi pendidikan alternatif dalam rangka menanamkan pendidikan karakter di seluruh lapisan masyarakat. Pesantren mampu menjaga eksistensinya sejak masa tradisional hingga modern saat ini, tentunya menerapkan pemaharuan dan perbaruan yang di sesuaikan dengan tuntutan zaman modern saat ini. 


\section{DAFTAR PUSTAKA}

Daliman, Islamisasi dan Perkembangan Kerajaan-Kerajaan Islam di Indonesia. Yogyakarta: Ombak. 2012.

A. Steenbrink Karel, Pesantren, Sekolah dan Madrasah, Pendidikan Islam dalam Kurun Modern. Jakarta, LP3ES, 1994.

Azyumardi Azra, Pendidikan Islam, Tradisi dan Modernisasi Menuju Milineum Baru, Bandung: Mizan.

Karel A. Steenbrink, Pesantren Madrasah Sekolah, Jakarta: LP3ES, 1986.

Mujamil Qomar, Dari Transformasi Metodologi Menuju Demokratisasi Institusi, Jakarta, Erlangga, 2007.

Azyumardi Azra, Pendidikan Islam Tradisi dan Modernisasi Menuju Milenium Baru, Jakarta: Logos Wacana Ilmu, 1999.

A.L. Tibawi, Islamic Education Its Traditions and Modernization into the Arab Nasional Sytems, London: Luzac \& Company LTD.

Fazlur Rahman, Islam, terj. Ahsin Muhammad, Bandung: Pustaka, 1994.

Ahmad Syalabi, Târîkh al Tarbiyah al Islâmiyyah, (al Qâhirah: al Maktabah al Anjilu, 1960.

Haidar Putra Daulay, Dinamika Pendidikan Islam di Asis Tenggara Jakarta: Rineka Cipta.2009.

Abudin Nata, 2009, Rekonstruksi Pendidikan Islam, Jakarta: Rajawali Press

Samsun Niam, Pendidikan Multi Kultur, Radar Jember, kamis 28 oktober 2010.

Zamakhsyari Dhofir, Tradisi Pesantren, LP3ES, Jakarta, 1992, hlm. 49

M. Sulthon dan Moh Khusnuridlo, Manajemen Pondok Pesantren dalam Perspektif Global, Yogyakarta: LaskBang Pressindo, 2006. 